\title{
Corpus Callosum Hyperintensity in Normal Pressure Hydrocephalus After Ventriculoperitoneal Shunt
}

Jinyoung Youn, MD, PhD, Gabor G. Kovacs, MD, PhD, Paul Kongkham, MD, PhD, and Alfonso Fasano, MD, PhD Neurology ${ }^{\circledR}$ 2021;96:1096-1097. doi:10.1212/WNL.0000000000012041

Figure Imaging Results

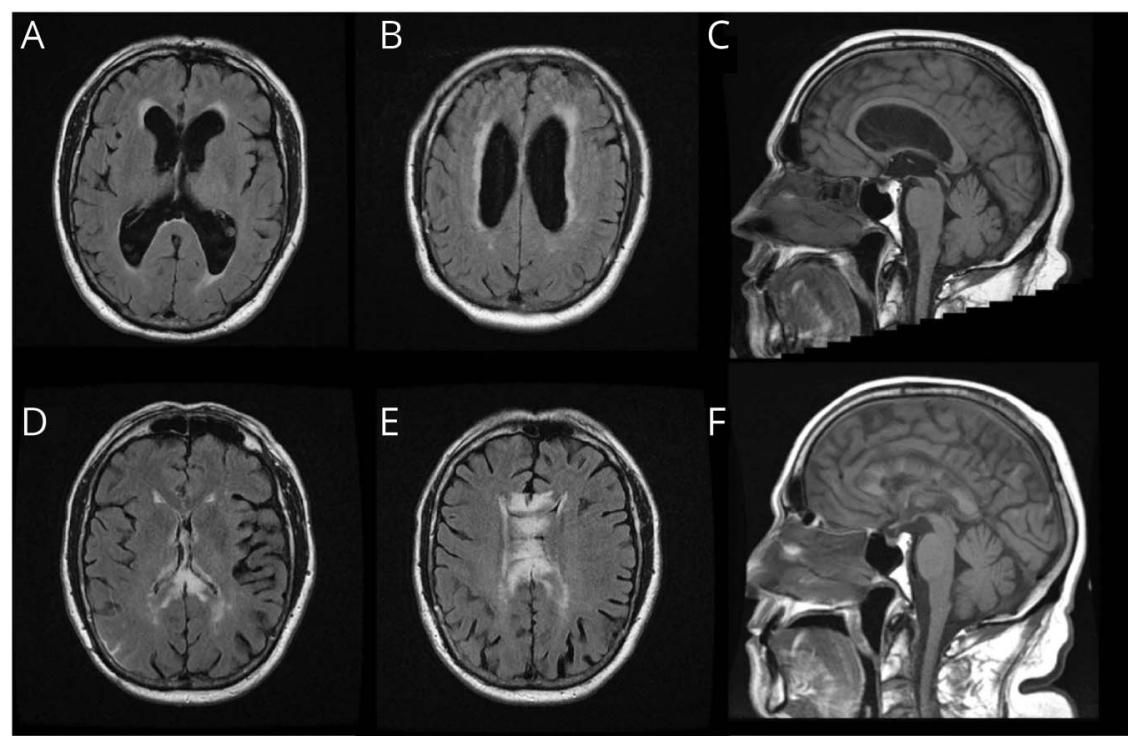

Ventriculomegaly on fluid-attenuated inversion recovery (FLAIR) axial image (A, B) and upward-displaced, thin corpus callosum on T1-weighted sagittal image (C) are visible before shunt surgery. Seven months after surgery, narrow ventricle and hyperintensities in corpus callosum on FLAIR axial images (D, E) and corpus callosum scalloping with signal change on T1-weighted sagittal image (F) are noticeable.

\section{Correspondence}

Dr. Fasano

alfonso.fasano@uhn.ca

A 73-year-old man presented with a 10-year history of gait instability, cognitive impairment, and urinary incontinence. Brain MRI (figure, $\mathrm{A}-\mathrm{C}$ ) and a positive response to tap test suggested a clinical diagnosis of normal pressure hydrocephalus (NPH). Venticulo-peritoneal shunt improved his symptoms without complications but was associated with changes in corpus callosum and narrow ventricle, possibly suggesting overdrainage (figure, D-F). Callosal stretch injury is poorly studied in NPH and rarely reported in postmortem NPH pathology. ${ }^{1}$ Although detected in patients treated for obstructive hydrocephalus, ${ }^{2}$ postshunt callosal hyperintensity is a poorly understood and little-known radiologic sign.

\section{Study Funding}

No targeted funding reported.

\section{Disclosure}

J. Youn received speaker's honoraria from SK Chemicals, Boston Scientific, and research support from Medtronic and Boston Scientific. G.G. Kovacs and P. Kongkham report no conflicts of

From the Department of Neurology (J.Y.), Sungkyunkwan University School of Medicine, and Neuroscience Center (J.Y.), Samsung Medical Center, Seoul, Korea; Edmond J. Safra Program in Parkinson's Disease, Morton and Gloria Shulman Movement Disorders Clinic (J.Y., G.G.K., A.F.), and Division of Neurosurgery, Department of Surgery (P.K.), Toronto Western Hospital; Division of Neurology (J.Y., G.G.K., A.F.), University of Toronto; and Krembil Brain Institute (G.G.K., A.F.), Toronto, Canada.

Go to Neurology.org/N for full disclosures. 
interest. A. Fasano received honoraria and/or research support from Abbott, AbbVie, Brainlab, Ceregate, Boston Scientific, Ipsen, Medtronic, Paladin Lab, Sunovion, and UCB Pharma. Go to Neurology.org/N for full disclosures.

Appendix Authors

\begin{tabular}{|c|c|c|}
\hline Name & Location & Contribution \\
\hline $\begin{array}{l}\text { Jinyoung } \\
\text { Youn, MD, } \\
\text { PhD }\end{array}$ & $\begin{array}{l}\text { Edmond J. Safra Program in } \\
\text { Parkinson's Disease, } \\
\text { Morton and Gloria } \\
\text { Shulman Movement } \\
\text { Disorders Clinic, Toronto } \\
\text { Western Hospital, UHN, } \\
\text { Canada }\end{array}$ & $\begin{array}{l}\text { Analyzed the data, drafted } \\
\text { the manuscript for } \\
\text { intellectual content }\end{array}$ \\
\hline $\begin{array}{l}\text { Gabor G. } \\
\text { Kovacs, MD, } \\
\text { PhD }\end{array}$ & $\begin{array}{l}\text { Edmond J. Safra Program in } \\
\text { Parkinson's Disease, } \\
\text { Morton and Gloria } \\
\text { Shulman Movement } \\
\text { Disorders Clinic, Toronto } \\
\text { Western Hospital, UHN, } \\
\text { Canada }\end{array}$ & $\begin{array}{l}\text { Interpreted the data, } \\
\text { revised the manuscript for } \\
\text { intellectual content }\end{array}$ \\
\hline
\end{tabular}

Appendix (continued)

\begin{tabular}{lll}
\hline Name & Location & Contribution \\
\hline $\begin{array}{l}\text { Paul } \\
\text { Kongkham, } \\
\text { MD, PhD }\end{array}$ & $\begin{array}{l}\text { Division of Neurosurgery, } \\
\text { Department of Surgery, } \\
\text { Toronto Western } \\
\text { Hospital, Ontario, } \\
\text { Canada }\end{array}$ & $\begin{array}{l}\text { Revised the manuscript for } \\
\text { intellectual content }\end{array}$ \\
& Edmond J. Safra & \\
Alfonso & $\begin{array}{l}\text { Program in Parkinson's } \\
\text { MD, PhD }\end{array}$ & $\begin{array}{l}\text { Designed and } \\
\text { conceptualized study, } \\
\text { interpreted the data, } \\
\text { revised the manuscript for } \\
\text { intellectual content }\end{array}$ \\
& $\begin{array}{l}\text { Gloria Shulman } \\
\text { Movement Disorders } \\
\text { Clinic, Toronto }\end{array}$ & \\
& Western Hospital, & \\
& UHN, Canada & \\
\hline
\end{tabular}

\section{References}

1. Espay AJ, Narayan RK, Duker AP, Barrett ET Jr, de Courten-Myers G. Lower-body parkinsonism: reconsidering the threshold for external lumbar drainage. Nat Clin Pract Neurol. 2008;4(1):50-55.

2. Lane JI, Luetmer PH, Atkinson JL. Corpus callosal signal changes in patients with obstructive hydrocephalus after ventriculoperitoneal shunting. AJNR Am J Neuroradiol. 2001;22(1):158-162.

\section{COVID-19 and Neurologic Disease: Call for Papers!}

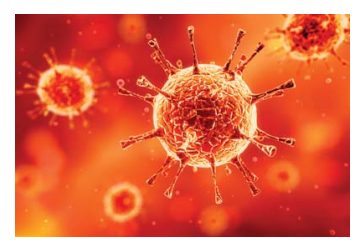

The editors of Neurology are interested in papers that address the neurological aspects of COVID-19 infection and challenges to the management of patients with chronic neurological conditions who have, or are at risk for, the infection. Relevant papers that pass initial internal review will undergo expedited peer review and online publication. We will consider papers posted in preprint servers.

Submit observational studies and clinical trials as Articles and case series and case reports under the Clinical/Scientific Notes category to https://submit.neurology.org/ today!

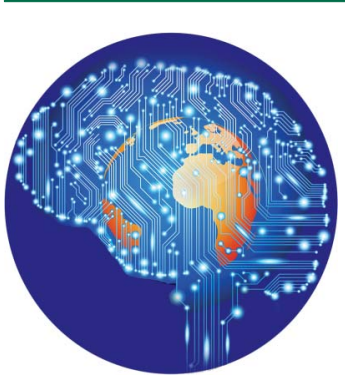

\section{Practice Current: An interactive exchange on controversial topics}

Share your own best practices.

Read commentary with expert opinion.

Explore results on an interactive world map.

NPub.org/NCP/practicecurrent

Neurology ${ }^{\circledR}$ Clinical Practice 


\section{Neurology}

\section{Corpus Callosum Hyperintensity in Normal Pressure Hydrocephalus After Ventriculoperitoneal Shunt \\ Jinyoung Youn, Gabor G. Kovacs, Paul Kongkham, et al. Neurology 2021;96;1096-1097 Published Online before print April 23, 2021}

DOI 10.1212/WNL.0000000000012041

This information is current as of April 23, 2021

\section{Updated Information \& Services}

References

Subspecialty Collections

Permissions \& Licensing

Reprints including high resolution figures, can be found at: http://n.neurology.org/content/96/23/1096.full

This article cites 2 articles, 1 of which you can access for free at: http://n.neurology.org/content/96/23/1096.full\#ref-list-1

This article, along with others on similar topics, appears in the following collection(s):

All Education

http://n.neurology.org/cgi/collection/all_education

Hydrocephalus

http://n.neurology.org/cgi/collection/hydrocephalus MRI

http://n.neurology.org/cgi/collection/mri

Information about reproducing this article in parts (figures,tables) or in its entirety can be found online at:

http://www.neurology.org/about/about_the_journal\#permissions

Information about ordering reprints can be found online:

http://n.neurology.org/subscribers/advertise

Neurology ${ }^{\circledR}$ is the official journal of the American Academy of Neurology. Published continuously since 1951, it is now a weekly with 48 issues per year. Copyright (O) 2021 American Academy of Neurology. All rights reserved. Print ISSN: 0028-3878. Online ISSN: 1526-632X.

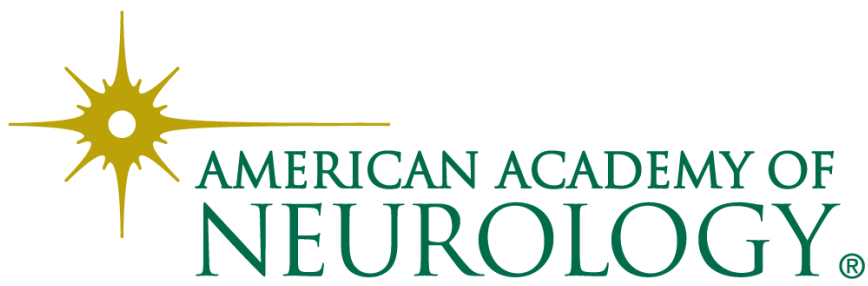

